\title{
New Insights into the Endocrine and Metabolic Roles of Dopamine D2 Receptors Gained from the $\mathrm{Drd2}^{-/-}$Mouse
}

\author{
Isabel Garcia-Tornadú Maria Ines Perez-Millan Victoria Recouvreux \\ Maria Cecilia Ramirez Guillermina Luque Gabriela Sofia Risso Ana Maria Ornstein
}

Carolina Cristina Graciela Diaz-Torga Damasia Becu-Villalobos

Instituto de Biología y Medicina Experimental, Consejo Nacional de Investigaciones Científicas y Técnicas, Buenos Aires, Argentina

\begin{abstract}
Key Words
Dopamine receptor $\cdot$ Transgenic mice $\cdot$ Prolactin $\cdot$

Growth hormone $\cdot$ Growth hormone-releasing hormone $\cdot$

Pancreas · Insulin · Food intake - Glucose metabolism
\end{abstract}

\section{Abstract}

Dopamine $\mathrm{D} 2$ receptor (D2R) participation in prolactin regulation is well documented, but the role of D2Rs in the control of other hormones involved in growth, food intake and glucose metabolism has not been extensively studied. The study of D2R knockout mice ( $\left.\mathrm{Drd2} 2^{--}\right)$puts forward new insights into the role of the D2R in growth hormone $(\mathrm{GH})$-releasing hormone-GH regulation, peptides involved in food intake, glucose homeostasis, as well as in prolactinoma development. The expected phenotype of chronic hyperprolactinemia and prolactinoma development was found in the $\mathrm{Drd2}^{-/-}$mouse, and this model constitutes a valuable tool in the study of dopamine-resistant prolactinomas. Unexpectedly, these mice were growth retarded, and the importance of functional hypothalamic D2Rs in the neonatal period was revealed. In the $\operatorname{Drd2}^{-/-}$mouse there was a failure of high neonatal GH levels and therefore the expansion of pituitary somatotropes was permanently altered. These mice also had increased food intake, and a sexually dimorphic participation of the D2R in food intake regulation is suggested. The effect described is probably secondary to $D 2 R$ regulation of prolactin secretion. Furthermore, the negative modulation of D2Rs on $\alpha$-melanocyte-stimulating hormone release and positive action on the hypothalamic expression of orexins reveals the complex D2R regulation of food intake. Finally, pancreatic D2Rs inhibit glucose-stimulated insulin release. Lack of dopaminergic inhibition throughout development in the $\mathrm{Drd}^{-/-}$mouse may exert a gradual deteriorating effect on insulin homeostasis, so that eventually glucose intolerance develops. These results highlight the complex endocrine actions of the D2Rs at different levels, hypothalamus, pituitary or pancreas, which function to improve fitness, reproductive success and survival.

Copyright $\odot 2010$ S. Karger AG, Basel

\section{Dopamine Receptors}

Throughout evolution the dopamine D2 receptor (D2R) has played an important role in a complex array of adaptive functions that improve fitness, reproductive success and survival. Selected mechanisms that increase

\section{KARGER}

Fax +4161306 1234

E-Mail karger@karger.ch

www.karger.com
(C) 2010 S. Karger AG, Basel

0028-3835/10/0924-0207\$26.00/0

Accessible online at:

www.karger.com/nen
Damasia Becu-Villalobos

Instituto de Biología y Medicina Experimental - CONICET

Vuelta de Obligado 2490, Buenos Aires 1428 (Argentina)

Tel. +54 114783 2869, Fax +54 1147862564

E-Mail dbecu@dna.uba.ar 
the probability of consuming nutritious food and couple with sexual partners recurrently use dopamine stimulation on this receptor subtype [1-3]. D2Rs are also fundamental in motor coordination, locomotor activity, executive planning, motivation or aversion and social dominance $[4,5]$. Furthermore, the participation of the D2R in endocrine function reinforces dopamine's role in reproductive success and survival $[6,7]$.

Five distinct dopamine receptors have been isolated, characterized and subdivided into two subfamilies, D1and D2-like, on the basis of their biochemical and pharmacological properties. The D1-like subfamily comprises D1- and D5R, while the D2-like subfamily includes D2-, D3- and D4R. D1 receptors are coupled to stimulatory G proteins, and the D2R subtype to inhibitory Gi/Go proteins [8]. Alternative splicing of the D2R yields long (D2L) and short (D2S) isoforms [9]. The short isoform has a 29-amino-acid deletion in the third intracytoplasmic domain, where interactions with Gi/Go proteins occur. Both isoforms have a similar binding affinity to dopamine, but they differ in their coupling to second messengers.

$\mathrm{D} 2 \mathrm{R}$ participation on prolactin regulation is well documented [6]; on the other hand, the role of D2Rs in the control of endocrine hormones controlling growth, food intake and glucose metabolism has not been extensively studied.

\section{Anterior Pituitary D2Rs}

At the pituitary level, D2Rs are expressed in lactotropes, where they are involved in the inhibition of prolactin release and synthesis, and lactotrope proliferation [6]. The D2L isoform is predominant [10], but D2S transgenic mice show lactotrope hypoplasia, highlighting the importance of this receptor subtype in prolactin control [11]. Furthermore, the D2L/D2S ratio is regulated by sex steroids [10].

\section{Brain and Peripheral D2Rs}

In brain tissues the $\mathrm{D} 2 \mathrm{R}$ is expressed predominantly in the basal ganglia, the nucleus accumbens and the frontal cortex where it participates in the extrapyramidal control of locomotor activity, the reinforcing properties of natural rewards and the spatiotemporal organization of goal-oriented behaviors, respectively $[2,12]$. In the brain the D2R is also expressed in the two isoforms, and the D2L is the most abundantly expressed [12]. Beyond the brain the D2R is localized in the retina, kidney, pancreas, and vascular system, besides the pituitary gland [8].

\section{D2Rs and Prolactin Regulation}

Dopamine inhibits prolactin secretion from lactotropes, and $\alpha$-melanocyte-stimulating hormone (MSH) secretion from melanotropes. Acting on lactotrope D2Rs it increases potassium conductance, hyperpolarizes the cell membrane, and suppresses adenylyl cyclase and inositol phosphate metabolism, leading to inhibition of lactotrope secretion and proliferation [6]. Prolactin release in rats is regulated by three hypothalamic dopaminergic neuronal systems, the tuberoinfundibular, the tuberohypophysial, and the periventricular dopaminergic systems [13]. Prolactin regulates its own release by affecting the hypothalamic dopaminergic neurons via a short loop negative feedback. The prolactin receptor (PRLR) colocalizes with neurons expressing tyrosine hydroxylase, the rate-limiting enzyme in dopamine synthesis [13]. During late pregnancy and lactation, and after prolactinoma formation, these neurons become refractory to prolactin-negative feedback enabling physiological or pathological hyperprolactinemia [13].

\section{Drd2 $2^{-/-}$Mice}

The $\mathrm{Drd} 2^{-/-}$mouse was generated by targeted mutagenesis [14]. Assessment of locomotor behavior of $\operatorname{Drd} 2^{-/-}$mice revealed a motor impairment, even though these mice did not show a compelling parkinsonian locomotor phenotype. Results predicted that locomotor activity is a polygenic trait that varies widely among inbred strains of mice [4]. On the other hand, this knockout mouse model yielded important results on the participation of the $\mathrm{D} 2 \mathrm{R}$ in endocrine and metabolic function.

\section{Prolactinoma Generation in the Drd2 $2^{-/-}$Mouse}

The physiological significance of D2R inhibitory control of prolactin was clearly appreciated in $\mathrm{Drd} 2^{-/-}$mice that displayed chronic hyperprolactinemia, and pituitary lactotrope hyperplasia [14], followed by lactotrope tumor formation [15]. Pituitary glands of the female $\operatorname{Drd2} 2^{-/-}$ mice had markedly increased number of lactotropes which were hyperstimulated with rapid turnover and limited storage capacity of prolactin [16]. The expression of the angiogenic protein, vascular endothelial growth factor-A (VEGF), was increased in pituitaries from $D r d 2^{-/-}$female mice, and increased pituitary VEGF expression was mainly dependent on the lack of dopaminergic control [17]. In contrast, pituitary tumor transforming gene product (PTTG) and fibroblast growth factor-2 (FGF2), two other angiogenic proteins, were not increased in the proliferating pituitary gland of the 
$\operatorname{Drd} 2^{-/-}$mouse $[18,19]$. Sarkar and colleagues $[20,21]$ previously demonstrated FGF2 and TGF- $\beta_{1}$ participation in pituitary tumor development in rats under pharmacological doses of estrogens. TGF- $\beta_{1}$ was decreased, but FGF2 was increased in the rat model in contrast with results in the $\operatorname{Drd2^{-/-}}$ mouse. This result may be related to the fact that $\mathrm{Drd} 2^{-/-}$female mice are hypoestrogenic. Moreover, it was reported that dopamine, acting on D2Rs, stimulates FGF2 expression in different areas of the brain [22], so the lack of dopaminergic tone in the $\mathrm{Drd} 2^{-/-}$female mice could be responsible for the low levels of FGF2 we determined both ex vivo and in pituitary cell culture [17].

Increased VEGF was expressed in follicle-stellate cells [17]. Because D2R receptors are found in lactotropes and not in follicle-stellate cells, it may be inferred that a paracrine-derived factor from lactotropes acts on follicle-stellate cells to increase VEGF expression. Even though VEGF did not promote pituitary cellular proliferation in vitro, as it does in endothelial cells, it may be critical for effective tumor angiogenesis, a process that increases the availability of different growth factors and mitogens, which is important for pituitary hyperplasia. Furthermore, VEGF may participate in increased prolactin secretion and in the marked peliosis observed in these adenomas [17]. Therefore, lack of pituitary D2Rs likely permits the development of tumors by increasing the population of proliferating cells that are susceptible to oncogenic and angiogenic factors, or mutation.

Low levels of FGF2 and PTTG may be related to the slow pace of pituitary tumor growth, the rarity of metastases [23], and the benign nature of the tumors.

\section{D2Rs and Prolactinoma Generation in Humans}

Prolactin adenomas are common monoclonal neoplasms accounting for approximately $30 \%$ of intracranial tumors. They can be effectively treated with dopaminergic agents and very rarely metastasize. But $15 \%$ of these may become resistant to classical pharmacological therapy, are invasive and aggressive, and require extirpation. Such resistance correlates in some cases with a lack of function or decreased expression of D2Rs; thus the $\mathrm{Drd} 2^{-/-}$female mouse is an excellent model to study prolactinoma dopamine resistance.

The molecular mechanisms related to dopamine resistance of some prolactinomas are not fully discovered. Mutations in the D2R gene have not been identified [24]. Instead, a decrease in the number and not in the binding affinity of D2Rs, and uncoupling of the D2R to second messengers have been described in dopamine-resistant prolactinomas $[25,26]$.

Dopamine D2 Receptors and Endocrine Function
In concordance with the proposed role on VEGF expression in our murine model, elevated serum VEGF concentrations [27] have been demonstrated in patients harboring pituitary tumors, and approximately $90 \%$ of human pituitary tumors cultured in vitro show measurable VEGF secretion [28].

We studied a cohort of human pituitary adenoma samples and found that VEGF protein expression was higher in dopamine-resistant prolactinomas compared to non-functioning, growth hormone $(\mathrm{GH})$ - and ACTHsecreting adenomas [29]. This finding may be related to the high percentage of macroprolactinomas in the series studied. To this respect, using angiogenic markers, it has been described that macroprolactinomas are significantly more vascularized than microprolactinomas [30].

These data indicate that even though the role of angiogenesis in pituitary adenomas is contentious [31], VEGF might contribute to adequate temporal vascular supply with mechanisms other than endothelial cell proliferation.

\section{D2Rs and GHRH-GH Regulation}

The role of dopamine on GH regulation has not been conclusively settled. Inhibitory as well as stimulatory effects of the amine have been reported on plasma levels of $\mathrm{GH}$ in vivo depending upon the experimental conditions used [32]. This may be explained by the ability of dopamine to release both GH-releasing hormone $(\mathrm{GHRH})$ and somatostatin from the rat hypothalamus [33]. In particular, it has been suggested that dopamine receptors can mediate the stimulation of GH by dopamine, provided other neural inhibitory inputs to the pituitary are removed. In vitro, positive as well as negative $\mathrm{GH}$ responses to the catecholamine have been described in pituitary cells [32, 34].

\section{GHRH-GH Axis in the Drd2 $2^{-/-}$Mouse}

The Drd2 $2^{-/-}$mouse was a useful model to unravel the participation of the D2R on growth and GHRH-GH regulation. These mice were growth retarded, evidencing an alteration in the GHRH-GH-insulin-like growth factor 1 (IGF-I) axis [35]. Growth retardation was evidenced starting on the second month of life. It was especially evident in male mice in which there was an overall body weight decrease of $15 \%$. Drd2 $2^{-/-}$females were smaller in the first months and there was a growth catch-up in the 3rd or 4th month.

Neuroendocrinology 2010;92:207-214 
Body length and the rate of skeletal maturation recapitulated the genotypic dimorphic pattern demonstrated for body weight. These results suggested that the D2R was involved, albeit indirectly, in body growth. Interestingly, high serum GH levels found in wild-type male and female mice in the first month of life were absent in $\mathrm{Drd} 2^{-/-}$mice. This developmental period is characterized by a low somatostatin inhibitory control at the pituitary level, as well as low expression of hypothalamic somatostatin $[36,37]$. The lack of increased GH levels in the first month of life had long-lasting consequences, as IGF-I levels as well as IGFBP-3 were reduced in adult $\mathrm{Drd} 2^{-/-}$mice, and even though serum GH levels were not different between genotypes there was a marked reduction in the percentage of pituitary somatotropes and GH content in adult Drd2 $2^{-/-}$mice [38].

We point to an involvement of $\mathrm{D} 2 \mathrm{R}$ signaling at the hypothalamic level as dopamine did not release GH acting at the pituitary level. Furthermore, $\mathrm{Drd} 2^{-/-}$mice had lower major urinary proteins indicating an altered $\mathrm{GH}$ pulsatility [7], and this difference could be caused by a different pattern of GHRH or somatostatin release and action. For example, in the lit/lit mouse, which has a point mutation in the Ghrh-R gene, major urinary proteins are also decreased [39].

Reduced levels of GHRH within the hypothalamus or altered GHRH action at the pituitary level during a critical developmental window have a lifelong impact on body weight [40-42], and induce an inadequate clonal expansion of the somatotrope population. The requirement of GHRH for the normal development of the somatotrope lineage is evident from studies examining the etiology of growth retardation in the spontaneous mutant mouse lit/ lit, [40] or in humans with mutations in the GHRH receptor [43]. Furthermore, GH pulsatility, which depends on an adequate temporal balance between GHRH and somatostatin output, might be compromised in Drd2 $2^{-/}$ mice, finally leading to lower IGF-I, and growth retardation.

\section{D2Rs and GH in Human Studies}

With regard to a possible role of the dopaminergic system in human growth, it has been shown that GH-deficient children increase their growth velocity after 6 months of L-DOPA treatment, even though the possible intervention of the adrenergic system was not tested [44]. On the other hand, it has been described that a group of children with idiopathic short stature had high frequencies of the A1 allele of the $D 2 R$, indicating a polymorphism of the receptor [45]. In these children there was a mild GH deficiency, decreased nocturnal GH secretion, slightly retarded bone maturation, and low blood levels of IGF-I.

D2Rs may also be involved in altered GH secretion in chronic treatment with antidopaminergic drugs. It has been described that during neuroleptic treatment of schizophrenic patients GH nocturnal rise is blunted, and this effect is related to the D2R binding capacity of neuroleptics used [46].

\section{D2Rs and Peptides Related to Food Intake}

Dopamine regulates hunger and satiety by acting in specific hypothalamic areas. The effects of dopamine on food intake have yielded conflicting results in the literature due to the different actions of dopamine on various hypothalamic nuclei, the involvement of multiple receptors, and different responses in food intake when administered systemically or locally into the hypothalamus [47]. Systemic treatment with D1/D2 agonists decreases food intake $[48,49]$, whereas it has also been described that selective D2R agonists may increase food intake [50]. Furthermore, different energy states (fasting, obesity, anorexia) modulate dopamine receptor expression $[51,52]$.

\section{Anorexigenic and Orexigenic Peptides in the \\ Drd2 $2^{-1-}$ Mouse}

In adult male and female $\mathrm{Drd} 2^{-/-}$mice, food intake per animal was unaltered, while food intake per gram body weight was increased. We found that in female and not in male mice, disruption of the $\mathrm{D} 2 \mathrm{R}$ produced two potentially anorexigenic events: an increase in serum and hypothalamic $\alpha-\mathrm{MSH}$, and a decrease in hypothalamic orexin expression [53]. The very high chronic prolactin levels found in this sex probably counterbalance these effects. In this regard it has been shown that prolactin stimulates food intake and fat deposition in female rats [54, 55], and that prolactin receptor-deficient mice have a progressive reduction in body weight, with females affected to a greater degree than males [56]. In $D r d 2^{-/-}$males, on the other hand, hypothalamic orexins and serum or hypothalamic $\alpha$-MSH were not modified, and therefore the moderate hyperprolactinemia may account for increased food intake. These results suggest a sexually dimorphic participation of the D2R in food intake regulation [53], probably secondary to their regulation of prolactin secretion. A negative modulation of $\mathrm{D} 2 \mathrm{Rs}$ on $\alpha-\mathrm{MSH}$ release and a positive action on the hypothalamic expression of 
orexins is also suggested, which may function to maintain food intake at almost equilibrium. These results reveal a participation of multiple factors in $\mathrm{D} 2 \mathrm{R}$ regulation of food intake.

\section{D2Rs and Food Intake in Humans}

In humans, reduction in D2Rs is associated with addictive behavior, towards food or drugs, and individuals with low numbers of D2Rs may be more vulnerable to addictive behaviors including compulsive food intake [57]. But, the involvement of dopamine in pathological eating and obesity is poorly understood. The evidence linking mutations of the $\mathrm{D} 2 \mathrm{R}$ gene and obesity syndromes in humans is limited, and in general, loss of function mutations associate with overweight $[58,59]$.

\section{D2Rs and Glucose Metabolism}

The relationship between dopamine receptors and glucose homeostasis has not been extensively studied, even though some clinical and experimental findings suggest a connection. In rodents, L-DOPA injection results in the accumulation of dopamine in pancreatic $\beta$ cells and an inhibitory action on insulin response to different secretagogues [60,61], whilst in male rats treated with a dopamine antagonist, high glucose and insulin levels were observed [62]. Insulin secretion is primarily controlled by metabolism-secretion coupling, and is mainly regulated by glucose, but this process can be modulated by the central nervous system through parasympathetic and sympathetic nerves [63].

Some in vitro studies performed in isolated pancreatic islets suggested the local participation of the D2R in insulin secretion [64-66], although the net effect of D2R stimulation observed in these studies and its functional importance remained controversial.

\section{Glucose Homeostasis in the Drd2 $2^{-1-}$ Mouse}

Glucose homeostasis was studied in $\mathrm{Drd} 2^{-/-}$mice, and in isolated islets from wild-type and $D r d 2^{-/-}$mice, using different pharmacological tools [67]. Drd2 $2^{-/-}$mice exhibited an impairment of insulin response to glucose, high fasting glucose levels, and were glucose intolerant. Glucose intolerance resulted from a blunted insulin secretory response, rather than insulin resistance, as shown by glucose-stimulated insulin secretion tests (GSIS) in vivo and in vitro, and by a conserved insulin tolerance test in vivo. On the other hand, short-term treatment with cabergoline, a dopamine agonist, resulted in glucose intolerance

Dopamine D2 Receptors and Endocrine Function and decreased insulin response to glucose in wild-type but not in $\mathrm{Drd} 2^{-/-}$mice; this effect was partially prevented by haloperidol, a D2R antagonist. In vitro results indicated that GSIS was impaired in pancreatic islets from $\operatorname{Drd} 2^{-/-}$mice, and that only in wild-type islets dopamine inhibited GSIS, an effect which was blocked by a D2R but not a D1R antagonist. Finally, immunohistochemistry showed a diminished pancreatic $\beta$-cell mass in $\operatorname{Drd} 2^{-/-}$ mice, and decreased $\beta$-cell replication in 2 -month-old $\operatorname{Drd} 2^{-/-}$mice.

Therefore, we conclude that pancreatic D2Rs inhibit glucose-stimulated insulin release. Lack of dopaminergic inhibition throughout development may exert a gradual deteriorating effect on insulin homeostasis, so that eventually glucose intolerance develops.

\section{D2Rs and Glucose Homeostasis in Humans}

Results obtained in $\mathrm{Drd2} 2^{-/}$mice are relevant in the analysis of some clinical findings such as the effect of chronic treatment with antipsychotic medications which can induce abnormalities in glucose metabolism that increase the risk for cardiovascular disease and diabetes [68-70], or the altered glucose tolerance associated to prolonged treatment with atypical antipsychotics in humans [58, 71-73]. Older diabetics who take antipsychotic medications have an increased risk of ending up in the hospital with elevated blood glucose levels, or hyperglycemia [74]. Conversely, treatment with the dopamine precursor L-DOPA in patients with Parkinson's disease reduces insulin secretion upon oral glucose tolerance test [75]. Recently, bromocriptine was approved by the FDA for the treatment of type 2 diabetes. The drug appears to employ central mechanisms in ameliorating hyperglycemia. Nevertheless, our studies indicate that pancreatic D2Rs could also participate in the effect of dopamine agonists.

\section{Conclusions}

In the $D r d 2^{-/-}$mouse the expected phenotype of chronic hyperprolactinemia and prolactinoma development was found, and this model proved to be valuable for studying dopamine-resistant prolactinomas where angiogenic and growth factors contribute to prolactinoma development. But, other endocrine profiles were uncovered. To begin with, mice were growth retarded, and the importance of functional hypothalamic D2Rs on GHRH$\mathrm{GH}$ in the neonatal period was revealed. These mice had also an increase in food intake, and a sexually dimorphic 
participation of the $\mathrm{D} 2 \mathrm{R}$ in food intake regulation is suggested. This effect was probably secondary to regulation of prolactin secretion. Furthermore, the negative modulation of D2Rs on $\alpha-\mathrm{MSH}$ release, and positive action on the hypothalamic expression of orexins revealed the complex D2R regulation of food intake. Finally, pancreatic D2Rs inhibited glucose-stimulated insulin release. Lack of dopaminergic inhibition throughout development in the $\mathrm{Drd} 2^{-/-}$mouse eventually led to glucose intolerance.
These results highlight the complex endocrine actions of the D2Rs at different levels, hypothalamus, pituitary or pancreas, which point to improve fitness, reproductive success and survival.

\section{Acknowledgements}

This work was supported by grants from CONICET (PIP 640 to D.B.-V.), Fundación Alberto J. Roemmers (D.B.-V.), Fundación Fiorini (D.B.-V.), and Agencia Nacional de Promoción Científica y Técnica, Buenos Aires, Argentina (PICT 2006, N206, to D.B.-V.).

\section{References}

$>1$ Salamone JD, Correa M, Mingote SM, Weber SM: Beyond the reward hypothesis: alternative functions of nucleus accumbens dopamine. Curr Opin Pharmacol 2005;5:34-41.

$>2$ Palmiter RD: Dopamine signaling in the dorsal striatum is essential for motivated behaviors: lessons from dopamine-deficient mice. Ann NY Acad Sci 2008;1129:35-46.

3 Missale C, Nash SR, Robinson S, Jaber M, Caron MG: Dopamine receptors: from structure to function. Physiol Rev 1998;78: 189-225.

4 Kelly MA, Rubinstein M, Phillips TJ, Lessov CN, Burkhart-Kasch S, Zhang G, Bunzow JR, Fang Y, Gerhardt GA, Grandy DK, Low MJ: Locomotor activity in D2 dopamine receptor-deficient mice is determined by gene dosage, genetic background, and developmental adaptations. J Neurosci 1998;18: 3470-3479.

$\checkmark 5$ Morgan D, Grant KA, Gage HD, Mach RH, Kaplan JR, Prioleau O, Nader SH, Buchheimer N, Ehrenkaufer RL, Nader MA: Social dominance in monkeys: dopamine D2 receptors and cocaine self-administration. Nat Neurosci 2002;5:169-174.

$\checkmark 6$ Ben-Jonathan N, Hnasko R: Dopamine as a prolactin inhibitor. Endocr Rev 2001;22: 724-763.

7 Garcia-Tornadu I, Risso G, Perez-Millan MI, Noain D, Diaz-Torga GS, Low MJ, Rubinstein M, Becu-Villalobos D: Neurotransmitter modulation of the GHRH-GH axis. Front Horm Res 2010;38:59-69.

$>8$ Missale C, Nash SR, Robinson SW, Jaber M, Caron MG: Dopamine receptors: from structure to function. Physiol Rev 1998;78: 189-225.

$>9$ Guiramand J, Montmayeur JP, Ceraline J, Bhatia M, Borrelli E: Alternative splicing of the dopamine D2 receptor directs specificity of coupling to G-proteins. J Biol Chem 1995; 270:7354-7358.
10 Guivarc'h D, Vernier P, Vincent JD: Sex steroid hormones change the differential distribution of the isoforms of the D2 dopamine receptor messenger RNA in the rat brain. Neuroscience 1995;69:159-166.

11 Iaccarino C, Samad TA, Mathis C, Kercret H, Picetti R, Borrelli E: Control of lactotrop proliferation by dopamine: essential role of signaling through D2 receptors and ERKs. Proc Natl Acad Sci USA 2002;99:1453014535.

12 De Mei C, Ramos M, Iitaka C, Borrelli E: Getting specialized: presynaptic and postsynaptic dopamine D2 receptors. Curr Opin Pharmacol 2009;9:53-58.

13 Ben-Jonathan N, LaPensee CR, LaPensee EW: What can we learn from rodents about prolactin in humans? Endocr Rev 2008;29: $1-41$.

14 Kelly MA, Rubinstein M, Asa SL, Zhang G, Saez C, Bunzow JR, Allen RG, Hnasko R, Ben-Jonathan N, Grandy DK, Low MJ: Pituitary lactotroph hyperplasia and chronic hyperprolactinemia in dopamine D2 receptordeficient mice. Neuron 1997;19:103-113.

15 Asa SL, Kelly MA, Grandy DK, Low MJ: Pituitary lactotroph adenomas develop after prolonged lactotroph hyperplasia in dopamine D2 receptor-deficient mice. Endocrinology 1999;140:5348-5355.

16 Cristina C, García-Tornadú I, Diaz-Torga G, Rubinstein M, Low MJ, Becu-Villalobos D: The dopaminergic D2 receptor knockout mouse: an animal model of prolactinoma. Front Horm Res 2006;35:50-63.

17 Cristina C, Diaz-Torga G, Baldi A, Gongora A, Rubinstein M, Low MJ, Becu-Villalobos D: Increased pituitary vascular endothelial growth factor-A in dopaminergic D2 receptor knockout female mice. Endocrinology 2005;146:2952-2962.
18 Cristina C, Diaz-Torga GS, Goya RG, Kakar SS, Perez-Millan MI, Passos VQ, GianellaNeto D, Bronstein MD, Becu-Villalobos D: PTTG expression in different experimental and human prolactinomas in relation to dopaminergic control of lactotropes. Mol Cancer 2007;6:4.

19 Cristina C, Diaz-Torga G, Gongora A, Guida MC, Perez-Millan MI, Baldi A, Becu-Villalobos D: Fibroblast growth factor-2 in hyperplastic pituitaries of D2R knockout female mice. Am J Physiol Endocrinol Metab 2007; 293:E1341-E1351.

20 Hentges, Boyadjieva N, Sarkar DK: Transforming growth factor- $\beta_{3}$ stimulates lactotrope cell growth by increasing basic fibroblast growth factor from folliculo-stellate cells. Endocrinology 2000;141:859-867.

-21 Pastorcic M, De A, Boyadjieva N, Vale W, Sarkar DK: Reduction in the expression and action of transforming growth factor- $\beta_{1}$ on lactotropes during estrogen-induced tumorigenesis. Cancer Res 1995;55:4892-4898.

22 Fumagalli F, Bedogni F, Maragnoli ME, Gennarelli M, Perez J, Racagni G, Riva MA: Dopaminergic D2 receptor activation modulates FGF-2 gene expression in rat prefrontal cortex and hippocampus. J Neurosci Res 2003;74:74-80

-23 Yamada S, Takada K: Angiogenesis in pituitary adenomas. Microsc Res Tech 2003;60: 236-243.

24 Friedman E, Adams HF, Hoog A, Gejman PV, Carson E, Larsson C, De Marco L, Werner S, Fahlbusch R, Nordenskjöld M: Normal structural dopamine type 2 receptor gene in prolactin-secreting and other pituitary tumors. J Clin Endocrinol Metab 1994;78:568574.

25 Caccavelli L, Feron F, Morange I, Rouer E, Benarous R, Dewailly D, Jaquet P, Kordon C, Enjalbert A: Decreased expression of the two D2 dopamine receptor isoforms in bromocriptine-resistant prolactinomas. Neuroendocrinology 1994;60:314-322. 
-26 Pellegrini I, Rasolonjanahary R, Gunz G, Bertrand P, Delivet S, Jedynak CP, Kordon C, Peillon F, Jaquet P, Enjalbert A: Resistance to bromocriptine in prolactinomas. J Clin Endocrinol Metab 1989;69:500-509.

27 Komorowski J, Jankewicz J, Stepien H: Vascular endothelial growth factor, basic fibroblast growth factor and soluble interleukin-2 receptor concentrations in peripheral blood as markers of pituitary tumours. Cytobios 2000;101:151-159.

28 Lohrer P, Gloddek J, Hopfner U, Losa M, Uhl E, Pagotto U, Stalla GK, Renner U: Vascular endothelial growth factor production and regulation in rodent and human pituitary tumor cells in vitro. Neuroendocrinology 2001;74:95-105.

-29 Cristina C, Perez-Millan MI, Luque G, Dulce RA, Sevlever G, Berner SI, Becu-Villalobos D: VEGF and CD31 association in pituitary adenomas. Endocr Pathol 2010;21:154-160.

- 30 Jugenburg M, Kovacs K, Stefaneanu L, Scheithauer BW: Vasculature in nontumorous hypophyses, pituitary adenomas, and carcinomas: a quantitative morphologic study. Endocr Pathol 1995;6:115-124.

- 31 De la Torre NG, Wass JA, Turner HE: Morphologic changes and molecular regulation of angiogenesis in pituitary adenomas. Front Horm Res 2004;32:133-145.

- 32 Muller EE, Locatelli V, Cocchi D: Neuroendocrine control of growth hormone secretion. Physiol Rev 1999;79:511-607.

- 33 Kitajima N, Chihara K, Hiromi H, Okimura Y, Fujii Y, Sato M, Shakutsui S, Watanabe M, Fufita T: Effects of dopamine on immunoreactive growth hormone-releasing factor and somatostatin secretion from rat hypothalamic slices perfused in vitro. Endocrinology 1989;124:69-76.

34 Bluet-Pajot MT, Mounier F, Durand D, Kordon C: Involvement of dopamine D1 receptors in the control of growth hormone secretion in the rat. J Endocrinol 1990;127: 191-196.

-35 Diaz-Torga G, Feierstein C, Libertun C, Gelman D, Kelly MA, Low MJ, Rubinstein M, Becu-Villalobos D: Disruption of the D2 dopamine receptor alters GH and IGF-I secretion and causes dwarfism in male mice. Endocrinology 2002;143:1270-1279.

- 36 Simonian SX, Murray HE, Gillies GE, Herbison AE: Estrogen-dependent ontogeny of sex differences in somatostatin neurons of the hypothalamic periventricular nucleus. Endocrinology 1998;139:1420-1428.

-37 Cuttler L, Welsh JB, Szabo M: The effect of age on somatostatin suppression of basal, growth hormone $(\mathrm{GH})$-releasing factorstimulated and dibutyryl adenosine $3^{\prime}-5^{\prime}$ monophosphate-stimulated $\mathrm{GH}$ release from rat pituitary cells in monolayer culture. Endocrinology 1986;119:152-158.
Garcia-Tornadu I, Rubinstein M, Gaylinn BD, Hill D, Arany E, Low MJ, Diaz-Torga G, Becu-Villalobos D: GH in the dwarf dopaminergic D2 receptor knockout mouse: somatotrope population, GH release, and responsiveness to $\mathrm{GH}$-releasing factors and somatostatin. J Endocrinol 2006;190:611619.

39 Al Shawi R, Wallace H, Harrison S, Jones C, Johnson D, Bishop JO: Sexual dimorphism and growth hormone regulation of a hybrid gene in transgenic mice. Mol Endocrinol 1992;6:181-190.

40 Lin SC, Lin CR, Gukovsky I, Lusis AJ, Sawchenko PE, Rosenfeld MG: Molecular basis of the little mouse phenotype and implications for cell type-specific growth. Nature 1993;364:208-213.

41 Cella SG, Locatelli V, Broccia ML, Menegola E, Giavini E, De Gennaro Colonna V, Torsello A, Wehrenberg WB, Muller EE: Long-term changes of somatotrophic function induced by deprivation of growth hormone-releasing hormone during the fetal life of the rat. J Endocrinol 1994;140:111-117.

42 Robinson GM, Spencer GS, Berry CJ, Dobbie PM, Hodgkinson SC, Bass JJ: Evidence of a role for growth hormone, but not for insulinlike growth factors-I and -II in the growth of the neonatal rat. Biol Neonate 1993;64:158165.

43 Maheshwari HG, Silverman BL, Dupuis J, Baumann G: Phenotype and genetic analysis of a syndrome caused by an inactivating mutation in the growth hormone-releasing hormone receptor: dwarfism of Sindh. J Clin Endocrinol Metab 1998;83:4065-4074.

44 Huseman CA, Hassing JM: Evidence for dopaminergic stimulation of growth velocity in some hypopituitary children. J Clin Endocrinol Metab 1984;58:419-425.

45 Miyake H, Nagashima K, Onigata K, Nagashima T, Takano Y, Morikawa A: Allelic variations of the $\mathrm{D} 2$ dopamine receptor gene in children with idiopathic short stature. J Hum Genet 1999;44:26-29.

46 Mann K, Rossbach W, Muller MJ, MullerSiecheneder F, Pott T, Linde I, Dittmann RW, Hiemke C: Nocturnal hormone profiles in patients with schizophrenia treated with olanzapine. Psychoneuroendocrinology 2006;31:256-264.

47 Ramos EJ, Meguid MM, Campos AC, Coelho JC: Neuropeptide Y, $\alpha$-melanocyte-stimulating hormone, and monoamines in food intake regulation. Nutrition 2005;21:269279.

48 Leibowitz SF: Brain monoamines and peptides: role in the control of eating behavior. Fed Proc 1986;45:1396-1403.

49 Terry P, Gilbert DB, Cooper SJ: Dopamine receptor subtype agonists and feeding behavior. Obes Res 1995(suppl 4):515S-523S.

50 Hillebrand JJ, de Wied D, Adan RA: Neuropeptides, food intake and body weight regulation: a hypothalamic focus. Peptides 2002; 23:2283-2306.
51 Fetissov SO, Meguid MM, Sato T, Zhang LH: Expression of dopaminergic receptors in the hypothalamus of lean and obese Zucker rats and food intake. Am J Physiol 2002; 283:R905-R910.

52 Sato T, Meguid MM, Fetissov SO, Chen C, Zhang L: Hypothalamic dopaminergic receptor expressions in anorexia of tumorbearing rats. Am J Physiol 2001;281:R1907R1916.

53 Garcia-Tornadu I, Diaz-Torga GS, Risso G, Silveyra P, Cataldi N, Ramirez MC, Low MJ, Libertun C, Becu-Villalobos D: Hypothalamic orexin, OX1, $\alpha$-MSH, NPY and MCRs expression in dopaminergic D2R knockout mice. Neuropeptides 2009;43:267-274.

54 Sauve D, Woodside B: The effect of central administration of prolactin on food intake in virgin female rats is dose-dependent, occurs in the absence of ovarian hormones and the latency to onset varies with feeding regimen. Brain Res 1996;729:75-81.

55 Naef L, Woodside B: Prolactin/leptin interactions in the control of food intake in rats. Endocrinology 2007; 148:5977-5983.

56 Freemark M, Fleenor D, Driscoll P, Binart N, Kelly PA: Body weight and fat deposition in prolactin receptor-deficient mice. Endocrinology 2001;142:532-537.

57 Palmiter RD: Is dopamine a physiologically relevant mediator of feeding behavior? Trends Neurosci 2007;30:375-381.

$58 \mathrm{Pijl}$ H: Reduced dopaminergic tone in hypothalamic neural circuits: expression of a 'thrifty' genotype underlying the metabolic syndrome? Eur J Pharmacol 2003;480:125131.

59 Fetissov SO, Meguid MM: On dopamine, D2 receptor, and Taq1A polymorphism in obesity and anorexia. Nutrition 2009;25:132133.

60 Ericson LE, Hakanson R, Lundquist I: Accumulation of dopamine in mouse pancreatic B-cells following injection of L-DOPA. Localization to secretory granules and inhibition of insulin secretion. Diabetologia 1977;13:117-124

61 Zern RT, Bird JL, Feldman JM: Effect of increased pancreatic islet norepinephrine, dopamine and serotonin concentration on insulin secretion in the golden hamster. Diabetologia 1980;18:341-346.

62 Baptista T, Lacruz A, Paez X, Hernandez L, Beaulieu S: The antipsychotic drug sulpiride does not affect body weight in male rats. Is insulin resistance involved? Eur J Pharmacol 2002;447:91-98.

63 Ahren B: Autonomic regulation of islet hormone secretion - implications for health and disease. Diabetologia 2000;43:393-410.

64 Nogueira CR, Machado UF, Curi R, Carpinelli AR: Modulation of insulin secretion and ${ }^{45} \mathrm{Ca}^{2+}$ efflux by dopamine in glucosestimulated pancreatic islets. Gen Pharmacol 1994;25:909-916. 
65 Rubi B, Ljubicic S, Pournourmohammadi S, Carobbio S, Armanet M, Bartley C, Maechler P: Dopamine D2-like receptors are expressed in pancreatic $\beta$ cells and mediate inhibition of insulin secretion. J Biol Chem 2005;280: 36824-36832.

-66 Shankar E, Santhosh KT, Paulose CS: Dopaminergic regulation of glucose-induced insulin secretion through dopamine D2 receptors in the pancreatic islets in vitro. IUBMB Life 2006;58:157-163.

67 Garcia-Tornadu I, Ornstein AM, ChamsonReig A, Wheeler MB, Hill DJ, Arany E, Rubinstein M, Becu-Villalobos D: Disruption of the dopamine D2 receptor impairs insulin secretion and causes glucose intolerance. Endocrinology 2010;151:1441-1450.
68 Amiel JM, Mangurian CV, Ganguli R, Newcomer JW: Addressing cardiometabolic risk during treatment with antipsychotic medications. Curr Opin Psychiatry 2008;21:613618.

69 Newcomer JW, Haupt DW, Fucetola R, Melson AK, Schweiger JA, Cooper BP, Selke G: Abnormalities in glucose regulation during antipsychotic treatment of schizophrenia. Arch Gen Psychiatry 2002;59:337-345.

70 Haupt DW, Newcomer JW: Hyperglycemia and antipsychotic medications. J Clin Psychiatry 2001;62(suppl 27):15-26.

71 Lebovitz HE: Metabolic consequences of atypical antipsychotic drugs. Psychiatr Q 2003;74:277-290.

72 Citrome L, Jaffe A, Levine J, Allingham B, Robinson J: Relationship between antipsychotic medication treatment and new cases of diabetes among psychiatric inpatients. Psychiatr Serv 2004;55:1006-1013.
73 Marder SR, Essock SM, Miller AL, Buchanan RW, Casey DE, Davis JM, Kane JM, Lieberman JA, Schooler NR, Covell N, Stroup S, Weissman EM, Wirshing DA, Hall CS, Pogach L, Pi-Sunyer X, Bigger JT Jr, Friedman A, Kleinberg D, Yevich SJ, Davis B, Shon S: Physical health monitoring of patients with schizophrenia. Am J Psychiatry 2004;161: 1334-1349.

74 Lipscombe LL, Levesque L, Gruneir A, Fischer HD, Juurlink DN, Gill SS, Herrmann N, Hux JE, Anderson GM, Rochon PA: Antipsychotic drugs and hyperglycemia in older patients with diabetes. Arch Intern Med 2009;169:1282-1289.

-75 Rosati G, Maioli M, Aiello I, Farris A, Agnetti V: Effects of long-term L-DOPA therapy on carbohydrate metabolism in patients with Parkinson's disease. Eur Neurol 1976;14: 229-239. 